\title{
Effect of different periods of pre-slaughter stress on the quality of the Nile tilapia meat
}

\author{
Pedro Luiz de CASTRO ${ }^{1 \star}$, Vanessa LEWANDOWSKI ${ }^{1}$, Maria Luiza Rodrigues de SOUZA², \\ Melina Franco CORADINI ${ }^{1}$, Alciony Andréia da Cunha ALEXANDRE ${ }^{1}$, César SARY ${ }^{1}$, Ricardo Pereira RIBEIRO ${ }^{2}$
}

\begin{abstract}
The study was carried out with the objective of evaluating the influence of pre-slaughter stress on meat quality of Nile tilapia (O. niloticus) for 10 days of storage in ice. 75 whole fish were used eviscerated, with average weight and length of $825.75 \pm 101.59 \mathrm{~g}$ and $28.25 \pm 0.81 \mathrm{~cm}$, respectively. The treatments consisted of time in which the animals underwent pre-slaughter hypoxia, being 0 , 3 and 6 minutes. Rigor mortis and muscle $\mathrm{pH}$ were assessed besides the application of the Quality Index Method and analysis of total protein and blood glucose. Rigor mortis did not differ among treatments during the storage period, and after three hours all animals were in rigor stage. The muscle $\mathrm{pH}$ values varied widely during the study period, observing higher values on the third day of storage. Sensory analysis showed that after 10 days the tilapia from the different treatments did not differ in the evaluated quality parameters similarly, there was no difference regarding the evaluated blood biochemical parameters Thus, hypoxia of 6 minutes pre-slaughter does not influence the rigor mortis, muscle $\mathrm{pH}$, qualitative perception of the meat quality, total protein and blood glucose of Nile tilapia.
\end{abstract}

Keywords: hypoxia; $\mathrm{pH}$; rigor mortis; quality index method; blood parameters.

Practical Application: Study the effects of pre-slaughter stress on the Nile tilapia meat quality.

\section{Introduction}

In Brazil, aquaculture has been showing strong growth in recent years, estimating a potential production of 20 million tones for the year of 2030 (Brasil, 2012), revealing to be a promising country in the production of aquatic organisms, as it has a coastline of approximately 8.5 thousand $\mathrm{km}$ and concentrates about $12 \%$ of all the fresh water on the planet (Cyrino et al., 2010). Besides the availability of water resources, the country has favorable climate, abundant manpower and growing demand for fish in the Internal Market (Della Flora et al., 2010).

The Nile tilapia stands out as the main species of fish produced in Brazil (Brasil, 2014). This is due to zootechnics characteristics favorable to breeding in captivity, such as rusticity, fast growing, easy reproduction, adaptation to different environments, among others (Kubitza, 2000). In addition, factors such as lack of spine "Y", fillet yield around 35\% of white meat of firm texture and slightly tangy flavor make it a proper species for processing and with good acceptance by the market (Jory et al., 2000).

During the cultivation period the fishes go through several situations of stress, which may be related to feeding, water quality, reproduction and especially the capture and pre-slaughter period. The pre-slaughter stress causes biochemical changes that influence the quality of meat of slaughtered animals, such as the rapid consumption of glycogen and ATP reserves and consequent production of lactic acid and decrease in muscle pH postmortem (Bagni et al., 2007).
The biochemical processes that occur after slaughter reflect on physical changes in the body of animals such as rigor mortis which is characterized by muscle rigidity as a result of irreversible consumption of ATP, that is, without regeneration of this energy source, it causes the decoupling of contractile proteins, actin and myosin (Oetterer et al., 2014). According to the authors, for greater freshness of the fish sold it is necessary that they are slaughtered immediately after capture to ensure the presence of glycogen and ATP for a longer period and thus delay the entry into rigor mortis.

The deterioration of fish after slaughter can also be detected by sensory analysis, involving the human senses of sight, touch, smell and taste in order to observe changes in appearance, odor, texture and taste of the product assessed. The Quality Index Method (QIM) is an important tool that can be used to evaluate the freshness of the fish. This method involves the assessment of various characteristics related to quality, such as appearance, texture, eyes, gills and abdomen, where each attribute receives a score that can range from zero to two, or from zero to three and the higher the score, the higher the degree of deterioration (Teixeira et al., 2009).

Thus, the aim of this study was to evaluate the rigor mortis, $\mathrm{pH}$, biochemical parameters of the blood and apply the Quality Index Method as a way to determine the freshness of whole Tilapias subjected to hypoxia at different times as a form of pre-slaughter stress.

${ }^{1}$ Post Graduate in Animal Production, Department of Animal Science, Agricultural Sciences Center, Universidade Estadual de Maringá - UEM, Maringá, PR, Brazil

${ }^{2}$ Department of Animal Science, Agricultural Sciences Center, Universidade Estadual de Maringá - UEM, Maringá, PR, Brazil

*Corresponding author: pedrocastro.zoo@hotmail.com 


\section{Materials and methods}

The survey was conducted at the Fish Culture Station (UEM-CODAPAR) located in Floriano district, Maringá, Paraná, Brazil, in November 2015. The methods follow the standards set of the Comitê Permanente de Ética em Pesquisa (COPEP) of the State University of Maringá (protocol number: 2378110815).

Initially, 75 fish were captured randomly with an average weight and length of $825.75 \pm 101.59 \mathrm{~g}$ and $28.25 \pm 0.81 \mathrm{~cm}$, respectively. The fish were submitted to a pre-slaughter stress, determined as the time they were out of water (0,3 and 6 minutes) before being slaughtered by hypothermia, without eviscerate with the use of tanks with water and ice at a ratio of 2:1.

Of the 75 fish used 30 were dedicated to evaluation of rigor mortis (ten per treatment - 0, 3 and 6 minutes) and 30 for blood biochemical analysis (ten per treatment), being 7 of these animals per treatment kept for the evaluation of muscle $\mathrm{pH}$, and five per treatment for sensory evaluation by the Quality Index method. Then the fish were placed in Styrofoam boxes and covered with ice scale in the ratio of $1: 1$.

\subsection{Rigor mortis evaluation}

The rigor mortis assessment was initiated immediately after slaughter in periods set at $0,3,6,9,12,18$ and 24 hours and then every 24 hours until the tenth day of storage. Rigor mortis index was evaluated according to the methodology described by Bito et al. (1983) and calculated according to the Equation 1:

$\mathrm{RI}=\frac{\mathrm{D}_{0}-\mathrm{D}}{\mathrm{D}_{0}} \times 100$

where RI = Rigor Index; D0 = value of the distance separating the base of the tail fin to the reference point, immediately after death, and $\mathrm{D}=$ distance value separating the base of the tail fin to the reference point in the selected time intervals. During this period, the animals were stored in cool boxes (Styrofoam) between layers of ice in the ratio of 1:1.

\subsection{Blood biochemical parameters}

To evaluate the blood biochemical parameters (glucose and total proteins), the animals were kept under hypoxia according to the period of each treatment ( 0,3 and 6 minutes) and then blood collection was carried out. $2.0 \mathrm{~mL}$ of blood were collected by caudal puncture with the use of syringe previously treated with EDTA anticoagulant (10\%) of 10 fish per treatment.

The samples were centrifuged for 10 minutes at $2000 \mathrm{rpm}$ in centrifuge to obtain serum, which was frozen at $-20^{\circ} \mathrm{C}$ for later analysis. Analyses were performed with the use of Gold Analisa Diagnóstica ${ }^{\circledast}$ specific kits, as instructed by the manufacturer with reading performed on spectrophotometer.

\section{$2.3 \mathrm{pH}$ analysis}

To determine the $\mathrm{pH}$ a portable $\mathrm{pH}$ meter (Hanna HI 991663 ) with drilling electrode was used. Three $\mathrm{pH}$ measures were made per fish, and the locations set in the animal's back, based on points at the beginning, middle and end of the dorsal fin. No point in the ventral area was determined, considering that the fish were not drawn, so by introducing the ph meter rupture of the internal viscera could happen.

The $\mathrm{pH}$ measurement was performed at predetermined times of $0,3,6,9,12,24$ hours and every 24 hours until the tenth day of storage. For this procedure the fish were kept in cool boxes with ice at a ratio of 1:1.

\subsection{Quality Index Method}

The determination of the QIM was conducted at the Animal Production Technology Laboratory of the State University of Maringa, using 5 fish per treatment, totaling 15 animals. For this sensory evaluation, five judges in the age group between 22 and 40 were selected and trained as described by Garcia (2015).

Four evaluation sessions were conducted at 1, 4, 7 and 10 days of storage with $45 \mathrm{~min}$ of duration. A Latin square design was conducted in each session, so that all judges would evaluate all 15 animals. The animals were identified with random coding labels of two digits and presented to the tasters in plastic trays, PVC type.

The judges were required to complete the evaluation sheet observing eight quality attributes in raw fish, taking into account the appearance, eyes, gills and abdominal wall, giving different scores on the degree of deterioration according to the table described by Garcia (2015) and presented in Table 1.

\subsection{Statistical analysis}

The index data of rigor mortis, $\mathrm{pH}$, biochemical blood parameters and value of the QIM were subjected to analysis of variance (ANOVA) with $95 \%$ of probability $(\mathrm{P}>0.05)$. When finding statistical difference between the different analyzes, the Tukey test was applied to level of $5 \%$ of significance to compare means with the software STATISTICA 7.0.

\section{Results and discussion}

\subsection{Rigor mortis}

Rigor mortis is a physical change that occurs in the muscle in response to chemical changes from deterioration or autolysis, which is characterized by being responsible for the beginning of the loss of fish quality (Oetterer et al., 2014). Thus, rigor mortis is an important parameter for determining meat quality, because it is directly related to the shelf life of the final product. After death, the muscle undergoes a series of biochemical transformations enhanced by pre-slaughter stress process, quickly depleting energy reserves, anticipating and shortening the time of the muscles rigor, unwanted feature for quality and durability of the final product (Sarmiento, 2006).

In this study, after slaughter (time 0 ) all fish showed flaccid aspect, with at least half of the body tilted, that is, zero percent of rigor mortis. However, after six hours of slaughter it was observed that $100 \%$ of fish had already entered in rigor and remained like this for 48 hours for the treatments of 0 and 3 minutes of subjection to pre-slaughter stress and up to 72 hours for the treatment with 6 minutes (Figure 1). 
Table 1. Quality Index Method for whole raw Nile Tilapia.

\begin{tabular}{|c|c|c|c|}
\hline & & Parameters & Demerit points \\
\hline \multirow{6}{*}{ Appearance } & \multirow{3}{*}{ Skin } & Bright, gray & 0 \\
\hline & & Less bright, slightly discolored & 1 \\
\hline & & Discolored, dull & 2 \\
\hline & \multirow{3}{*}{ Meat firmness } & Firm, elastic & 0 \\
\hline & & Less firm and still elastic & 1 \\
\hline & & Soft, plastic & 2 \\
\hline \multirow{9}{*}{ Eyes } & \multirow{3}{*}{ Cornea } & Clear, transparent & 0 \\
\hline & & Slightly blurred & 1 \\
\hline & & Blurred & 2 \\
\hline & \multirow{3}{*}{ Pupil } & Black, bright & 0 \\
\hline & & Slightly gray & 1 \\
\hline & & Gray & 2 \\
\hline & \multirow{3}{*}{ Shape } & Convex & 0 \\
\hline & & Flat & 1 \\
\hline & & Concave, deepened & 2 \\
\hline \multirow{7}{*}{ Gills } & \multirow{4}{*}{ Odor } & Algae, fresh & 0 \\
\hline & & Metallic & 1 \\
\hline & & Abnormal smell: slightly moldy, sour, oxidized & 2 \\
\hline & & Sour, sulfidric, moldy, putrid & 3 \\
\hline & \multirow{3}{*}{ Color } & Bright red & 0 \\
\hline & & Slightly discolored & 1 \\
\hline & & Discolored, greenish, brownish, yellowish & 2 \\
\hline \multirow{3}{*}{ Abdomen } & \multirow{3}{*}{$\begin{array}{l}\text { Abdominal } \\
\text { wall }\end{array}$} & Firm, intact & 0 \\
\hline & & Less firm, but still intact & 1 \\
\hline & & Soft, com marks, torn & 2 \\
\hline \multicolumn{3}{|c|}{ Quality Index (Total of demerit points) } & $0-17$ \\
\hline
\end{tabular}

Source: Garcia (2015).

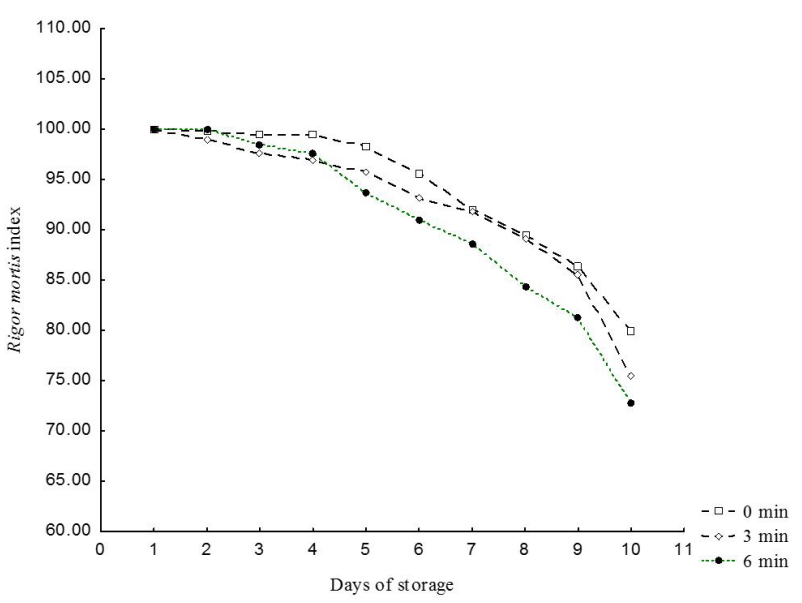

Figure 1. Percentage of animals subjected to the times of 0,3 and 6 minutes of pre-slaughter stress, which remained in rigor mortis after ten days of storage.

This result is corroborated by Oliveira et al. (2015), who obtained $100 \%$ of rigor mortis for the same species between six and seven hours after slaughter. Pedrazzani et al. (2009) also found similar results when comparing the effect of two desensibility methods for Nile tilapia, wherein the rigor mortis has been reached between 8 and 9 hours after slaughter. Moreover, Batista et al. (2004) and Almeida et al. (2005) mentioned that when slaughtering specimens of matrinxã (Brycon cephalus) and tambaqui (Colossoma macropomum) respectively, rigor mortis was established much earlier, between 30 and 75 minutes. This suggests that the species respond differently on this parameter, which may be related among other factors to the slaughter method and the muscle fiber profile of each species.

Although no statistically significant differences were found between treatments $(p>0.05)$, there was an early exit tendency of rigor mortis. Fish subjected to pre slaughter stress (3 and 6 min), a difference that could have been observed if the experimental period had been extended, as Oliveira et al. (2015) observed that the Nile tilapia left the rigor mortis state only 12 days after slaughter.

Without rigor mortis the fish changes start to occur by microbial activity, with high proliferation of these organisms, once they start to have as substrate hydrolyzed products formed by autolysis of muscle fibers (Araújo et al., 2010), in this case, some technologies can be used in order to slow the deterioration of fish and allow extended life of the final product.

\section{$3.2 p H$}

Shortly after slaughter, the average $\mathrm{pH}$ of the meat were $6.97 \pm 0.19,6.89 \pm 0.14$ and $7.02 \pm 0.25$ for the control treatment and for the treatments at three and six minutes respectively not 
being observed statistically significant differences $(p>0.05)$ between treatments. These values were in agreement with Baygar et al. (2012) that defined $\mathrm{pH}$ close to 7 as the ideal for the fish muscle. The $\mathrm{pH}$ of tilapia meat in the control group and at three and six minute pre slaughter hypoxia at times $0,3,9,12,24$ and every 24 hours up to 240 hours is shown in Figure 2.

In the first 24 hours after slaughter an increase in $\mathrm{pH}$ was observed, reaching $7.18 \pm 0.11$ for the treatment with high load of stress, since a decrease in the $\mathrm{pH}$ of the meat was expected, for it is in this period that muscles glycogen reserves are transformed by anaerobic via into lactic acid (Acerete et al., 2009). One explanation for this may have been established by the chronic stress state in the sampled fish, caused among other things by the low quality water and high stocking densities. However, Vargas (2011) mentions that the intensification of fish meat acidity occurs after approximately 56 hours of storage, a result similar to that found by this research, in which the lowest $\mathrm{pH}$ was obtained exactly between 48 and 72 hours.

The increase in $\mathrm{pH}$ from the third to the ninth day, reaching $7.41 \pm 0.09$ for the treatment with 6 minutes of hypoxia is consistent with that found by Conde (1975). Soares et al. (1998) observed similar behavior, in which at the beginning of rigor mortis, the fish $\mathrm{pH}$ dropped from 7.0 to 6.5 and later rising to 6.6 up until 6.8. However, Prata (1999) reports that the meat of the fish for consumption should not have $\mathrm{pH}$ higher than 7.0.

This great increase in $\mathrm{pH}$ may be due to bacterial contamination during storage, since bacterial metabolic activity decomposes nitrogen compounds for the formation of compounds such as ammonia and trimethylamine, increasing the $\mathrm{pH}$ (Scherer et al., 2006). This result may have been interfered by the need of daily manipulation of fish and cuts in the skin to insert the probe of the $\mathrm{pH}$ meter, cuts that provided an enabling environment for bacterial growth.

The drop in $\mathrm{pH}$ observed on the tenth day coincided with the moment of highest value of demerit points (QIM) and the greater loss of rigor mortis showing the direct association of these parameters with the final quality of the meat.

\subsection{Method of Quality Index (QIM)}

The sensory analysis performed by QIM showed a significant difference $(\mathrm{P}<0.05)$ compared to the average of the quality criteria only on the first day of storage, in which the animals that underwent six minutes of hypoxia before slaughter had higher scores (Figure 3). When considering the storage period a significant difference $(\mathrm{P}<0.05)$ was observed compared to everyday sensory analysis.

The quality of the fish meat is changed by both the method of slaughter, as well as the handling of animals in the pre-slaughter phase, since, in stressful situations they increase muscle activity, which influences the biochemical muscle reactions, directly affecting the rigor mortis, $\mathrm{pH}$, autolysis and therefore the final quality of the product (Morzel et al., 2006). When fish are subjected to hypoxia during pre-slaughter and slaughter increase in stress level occurs resulting in increased muscle activity through vigorous movements (Bagni et al., 2007), causing an increase

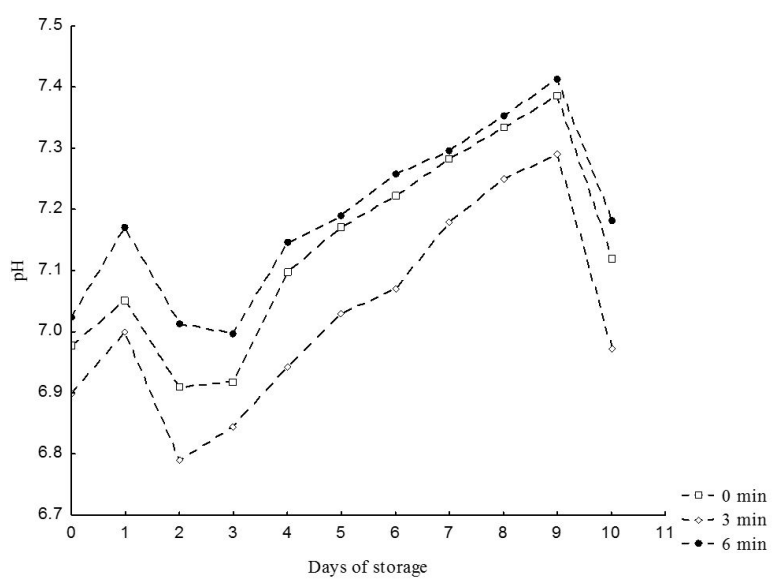

Figure 2. Muscle $\mathrm{pH}$ of tilapia subjected to different times of pre-slaughter hypoxia during 10 days of storage on ice.

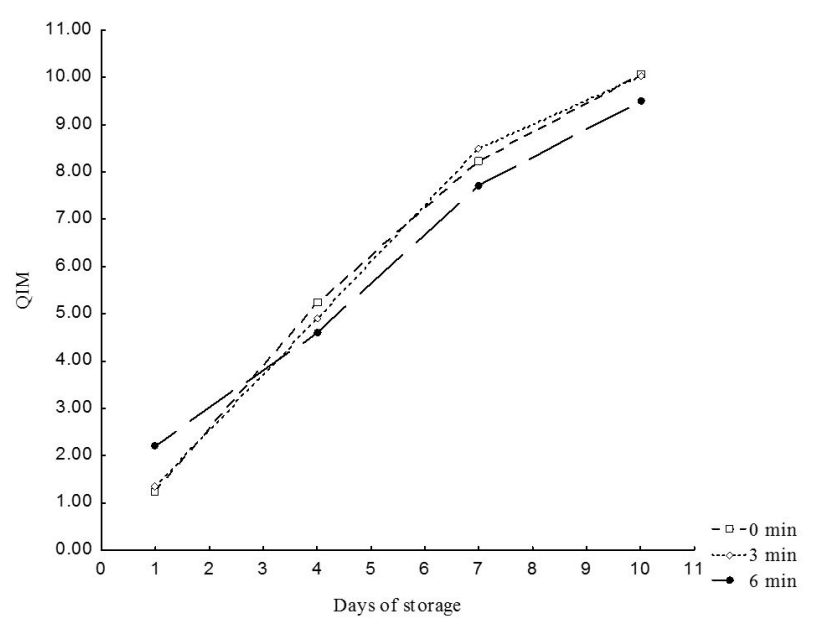

Figure 3. QIM value of Nile Tilapia subjected to hypoxia at different times before slaughter for 10 days of storage in ice.

in the anaerobic energy metabolism based on fermentation of glycogen or glucose (Jorgensen \& Mustafa, 1980).

Studies related to the time necessary for death by hypoxia show that fish species differ in their resistance period to lack of oxygen. Rahmanifarah et al. (2011) evaluated three slaughter methods for common carp (Cyprinus carpio L.) and found that the animals died after five hours of hypoxia, being the resistance of this species to lack of oxygen, while the rainbow trout (Oncorhynchus mykiss) was slaughtered with fifteen minutes of hypoxia (Kestin et al., 1991). Ferreira et al. (2011) stated that Nile tilapia is resistant to hypoxia which would explain the fact that the meat quality parameters evaluated in this study have not presented significant differences in relation to the applied hypoxia times.

The increase in the demerit score observed in relation to the days of storage reflect the autolysis process caused by bacterial decomposition of protein and fat, which impacts directly on the meat quality parameters evaluated in sensory analysis and 
corroborate the results found for other species fish such as hybrid tambacu (Colossoma macropomum x Piaractus mesopotamicus), Pintado da Amazônia (Pseudoplatistoma fasciatum x Leiarius marmoratus), hybrid tambatinga (Colossoma macropopum $\mathrm{x}$ Piaractus brachypomum), corvina (Micropogonias furnieri), among others (Teixeira et al., 2009; Borges et al., 2014; Lanzarin et al., 2016; Ritter et al., 2016).

QIM values regarding the quality attributes evaluated did not differ significantly $(\mathrm{P}>0.05)$ between treatments on different days (Table 2). There was only difference in score between treatments considering the animals evaluated on a day of storage, where fish subjected to hypoxia 6 minutes pre-slaughter had higher scores for skin attributes, meat firmness, cornea, pupil, color and odor of gills and abdominal wall.

By evaluating the means of the attributes regarding the storage, significant difference $(\mathrm{p}<0.05)$ between everyday sensory analysis was observed. On the first day of storage the attributes that had higher score were skin, cornea and pupil, and from the fourth day on, the shape of the eye also had increased score, standing out from the other attributes such as firmness of the meat, odor and color of the gills and abdominal wall (Figure 4).

From the seventh day changes in the quality of tilapia were more expressive, and skin was less bright and slightly discolored and the gills odor appeared as metallic. The odor is the main cause of the reduction of the acceptability of the fish, and that modifications in the gills are due to alterations of the hemoglobin molecule, responsible for the body oxygen transport, transforming oxyhemoglobin (hemoglobin combined with four molecules of oxygen) in methemoglobin (hemoglobin unable to carry oxygen due to the oxidation of $\mathrm{Fe}^{2+}$ of the heme group into $\mathrm{Fe}^{3+}$ ), besides the actions of microbiological and enzymatic nature (Lanzarin et al., 2016; Ritter et al., 2016).

For the eyes, it was observed that the cornea and pupil were classified as slightly turbid and slightly gray, respectively. The shape of the eye had significant change, no longer considered flat. According to Huss (1995) the eyeball begins to suffer changes and modify its structure due to degradation by autolysis at the beginning of the deterioration process.

On the tenth day of storage, the shape of the eye kept with higher demerit score in relation to other attributes, while meat firmness remained with lower scores in all evaluations, keeping the color and brightness. However, none of these parameters reached the highest score, indicating that after 10 days of ice storage, tilapias were not completely deteriorated. These results corroborate with Borges et al. (2014), who evaluated the quality parameters of hybrid tambacu (Colossoma macropomum $\mathrm{x}$ Piaractus mesopotamicus) and observed that the shape of the eye and odor of the gills had major changes during 16 days of storage, while the firmness of the meat was the attribute that had minor change.

\subsection{Blood biochemical parameters}

Significant difference $(\mathrm{P}>0.005)$ was observed for the biochemical blood parameters. It was observed that the amount of plasma protein of tilapia subjected to 6 minutes of hypoxia

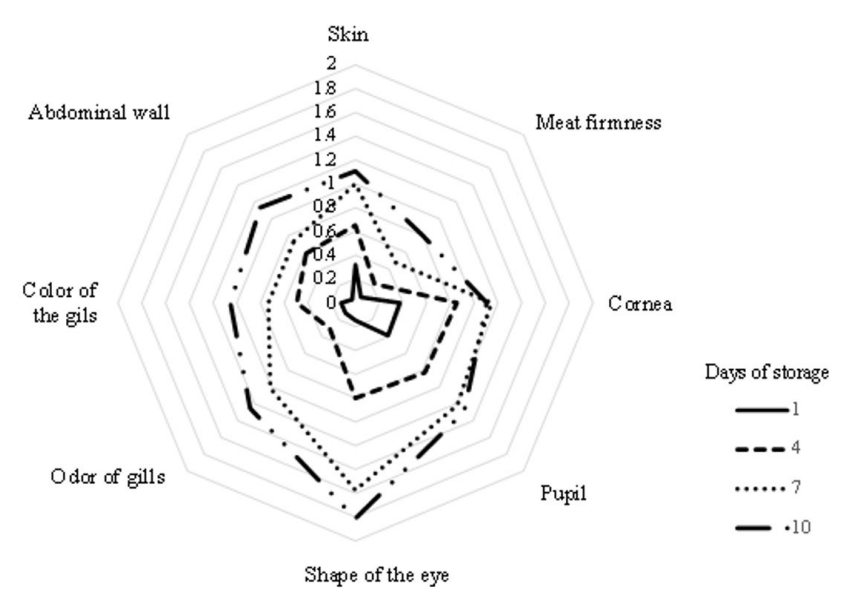

Figure 4. Mean of fish quality attributes evaluated by QIM of Nile tilapia for 10 days of storage in ice.

Table 2. Demerit points means of the quality attributes of the Nile tilapia fish subjected to different hypoxia times before slaughter on different days of storage on ice by the quality index method (QIM).

\begin{tabular}{|c|c|c|c|c|c|c|c|c|c|c|}
\hline \multirow{2}{*}{ D } & \multirow{2}{*}{$\mathbf{T}$} & \multicolumn{2}{|c|}{ Appearance } & \multicolumn{3}{|c|}{ Eyes } & \multicolumn{2}{|c|}{ Gills } & \multirow{2}{*}{$\begin{array}{c}\text { Abdomen } \\
\text { AW } \\
\end{array}$} & \\
\hline & & Skin & MF & Cornea & Pupil & Shape & Color & Odor & & \\
\hline \multirow[t]{3}{*}{1} & 0 & $0.32 \pm 0.4$ & $0.08 \pm 0.1$ & $0.24 \pm 0.4$ & $0.28 \pm 0.2$ & $0.04 \pm 0.1$ & $0.04 \pm 0.1$ & $0.12 \pm 0.3$ & $0.00 \pm 0.0$ & NS \\
\hline & 3 & $0.24 \pm 0.2$ & $0.00 \pm 0.0$ & $0.28 \pm 0.2$ & $0.40 \pm 0.2$ & $0.32 \pm 0.5$ & $0.12 \pm 0.1$ & $0.00 \pm 0.0$ & $0.04 \pm 0.1$ & NS \\
\hline & 6 & $0.40 \pm 0.2$ & $0.12 \pm 0.2$ & $0.60 \pm 0.4$ & $0.48 \pm 0.3$ & $0.08 \pm 0.2$ & $0.20 \pm 0.2$ & $0.24 \pm 0.2$ & $0.08 \pm 0.1$ & NS \\
\hline \multirow[t]{2}{*}{4} & 0 & $0.60 \pm 0.3$ & $0.28 \pm 0.3$ & $0.80 \pm 0.5$ & $0.76 \pm 0.5$ & $0.60 \pm 0.5$ & $0.32 \pm 0.4$ & $0.80 \pm 0.2$ & $0.64 \pm 0.3$ & NS \\
\hline & 3 & $0.64 \pm 0.2$ & $0.20 \pm 0.1$ & $0.88 \pm 0.2$ & $0.84 \pm 0.2$ & $0.88 \pm 0.5$ & $0.36 \pm 0.3$ & $0.52 \pm 0.5$ & $0.52 \pm 0.4$ & NS \\
\hline \multirow{2}{*}{7} & 3 & $1.08 \pm 0.2$ & $0.48 \pm 0.1$ & $1.40 \pm 0.4$ & $1.36 \pm 0.3$ & $1.48 \pm 0.6$ & $0.96 \pm 0.2$ & $1.00 \pm 0.4$ & $0.72 \pm 0.4$ & NS \\
\hline & 6 & $1.00 \pm 0.2$ & $0.48 \pm 0.0$ & $1.08 \pm 0.4$ & $1.12 \pm 0.3$ & $1.56 \pm 0.7$ & $0.96 \pm 0.2$ & $0.72 \pm 0.2$ & $0.80 \pm 0.3$ & NS \\
\hline \multirow[t]{3}{*}{10} & 0 & $1.08 \pm 0.2$ & $0.84 \pm 0.2$ & $0.96 \pm 0.4$ & $1.16 \pm 0.3$ & $1.92 \pm 0.3$ & $1.16 \pm 0.3$ & $0.84 \pm 0.1$ & $1.16 \pm 0.4$ & NS \\
\hline & 3 & $1.00 \pm 0.2$ & $0.88 \pm 0.1$ & $1.44 \pm 0.4$ & $1.48 \pm 0.5$ & $1.72 \pm 0.5$ & $1.16 \pm 0.2$ & $1.16 \pm 0.6$ & $1.20 \pm 0.2$ & NS \\
\hline & 6 & $1.24 \pm 0.2$ & $0.68 \pm 0.1$ & $0.92 \pm 0.4$ & $1.24 \pm 0.2$ & $1.80 \pm 0.2$ & $1.44 \pm 0.2$ & $1.16 \pm 0.4$ & $1.04 \pm 0.2$ & NS \\
\hline
\end{tabular}

$\mathrm{D}=$ Day; $\mathrm{T}=$ Tratament $(\mathrm{min}) ; \mathrm{MF}=$ Meat firmness; $\mathrm{AW}=$ abdominal wall; $\mathrm{NS}=$ not significant $(\mathrm{P}>0.05)$ by Tukey test. 
Table 3. Means protein and plasma glucose of tilapia subjected to different hypoxia times before slaughter.

\begin{tabular}{ccc}
\hline Treatment & $\begin{array}{c}\text { Total Plasma Protein } \\
(\mathrm{g} / \mathbf{d L})\end{array}$ & Glucose $(\mathbf{m g} / \mathbf{d L})$ \\
\hline 0 min & $3.44 \pm 0.26$ & $165.58 \pm 33.96$ \\
3 min & $3.70 \pm 0.62$ & $188.73 \pm 75.82$ \\
6 min & $3.76 \pm 0.46$ & $155.37 \pm 42.36$ \\
\hline
\end{tabular}

On the other hand, blood glucose of the fish subjected to a longer time of pre slaughter.

was increased when compared to animals slaughtered without remaining in hypoxia, being $3.76 \pm 0.46$ and $3.44 \pm 0.26$ (g/dL), respectively (Table 3 ).

hypoxia was lower than those slaughtered at 0 and 3 minutes without oxygen before slaughter. According to Higuchi et al. (2011), the biochemical plasma parameters detected disorders in the functioning of organs and animal adaptations before stress conditions, where glucose is a indicative parameter of physiological changes, since it is the main source of energy used by fish to withstand adverse conditions (Morgan \& Iwana, 1997; Urbinatti et al., 2004). Thus, the smallest amount of blood glucose of the tilapias subjected to 6 minutes of pre-slaughter hypoxia increased the use of this molecule in biochemical reactions in the body.

According to Poli et al. (2005), the capture and pre-slaughter duration is very traumatic for the fish, due to the struggle and agglomeration occurring during these processes. If the pre-slaughter traumatic situation lasts for a long period of time, the lactic acid produced will gradually be eliminated from the blood, but the energy will gradually become exhausted. When the fish is killed, the $\mathrm{pH}$ will remain higher due to the early end of the post-mortem anaerobic glycolysis caused by the shortage of the energy sources (Poli et al., 2005).

\section{Conclusions}

The hypoxia time of 6 minutes in the pre-slaughter of tilapia does not influence the rigor mortis, $\mathrm{pH}$, meat quality attributes observed by means of sensory analysis by the Quality Index Method neither the concentration of total protein and plasma glucose.

\section{References}

Acerete, L., Reig, L., Alvarez, D., Flos, R., \& Tort, L. (2009). Comparison of two stunning/slaughtering methods on stress response and quality indicators of European sea bass (Dicentrarchus labrax). Aquaculture, 287(1-2), 139-144. http://dx.doi.org/10.1016/j.aquaculture.2008.10.012.

Almeida, N. M., Batista, G. M., Kodaira, M., Val, A. L., \& Lessi, E. (2005). Determinação do índice de rigor-mortis e sua relação com a degradação dos nucleotídeos em tambaqui (Colossoma macropomum), de piscicultura e conservados em gelo. Ciência Rural, 35(3), 698-704. http://dx.doi.org/10.1590/S0103-84782005000300034.

Araújo, D. A. F. V., Soares, K. M. P., \& Gois, V. A. (2010). Características gerais, processos de deterioração e conservação do pescado. Pubvet, 4(9), 771.

Bagni, M., Civitareale, C., Priori, A., Ballerini, A., Finoia, M., Brambilla, G., \& Marino, G. (2007). Pre-slaughter crowding stress and killing procedures affecting quality and welfare in sea bass (Dicentrarchus labrax) and sea bream (Sparus aurata). Aquaculture, 263(4), 52-60. http://dx.doi.org/10.1016/j.aquaculture.2006.07.049.

Batista, G. M., Lessi, E., Kodaira, M., \& Falcão, P. T. (2004). Alterações bioquímicas post-mortem de matrinxã (Brycon cephalus) (Günther, 1869) procedente da piscicultura, mantido em gelo. Ciência e Tecnologia Alimentar, 24(4), 573-581. http://dx.doi.org/10.1590/ S0101-20612004000400016.

Baygar, T., Alparslan, Y., \& Kaplan, M. (2012). Determination of changes in chemical and sensory quality of sea bass marinades stored at $+4( \pm 1)^{\circ} \mathrm{C}$ in marinating solution. Journal of Food, 10(3), 196-200.

Bito, M., Yamada, K., Mikumo, Y., \& Amano, K. (1983). Studies on rigor mortis of fish, Difference in the mode of rigor mortis among some varieties of fish by modified Cutting's method. Tokai Regional Fisheries Research Laboratory, 109(1), 89-96.

Borges, A., Conte-Junior, C. A., Franco, R. M., Mársico, E. T., \& Freitas, M. Q. (2014). Quality index methos (QIM) for the hybrid tambacu (Colossoma macropomum x Piaractus mesopotamicus) and the correlation among its quality parameters. $L W T$-Food Science and Technology, 56(2), 432-439. http://dx.doi.org/10.1016/j.lwt.2013.12.008.

Brasil. Ministério da Pesca e Aquicultura - MPA. (2012). Boletim estatístico da pesca e aquicultura. Brasília.

Brasil. Ministério da Pesca e Aquicultura - MPA. (2014). Potencial brasileiro de produção de pescados. Brasília.

Conde, J. M. M. (1975). Guia del inspector veterinário titular: 1- bromotologia sanitária (1st ed.). Barcelona: Biblioteca Veterinária Aedos.

Cyrino, J. E. P., Bicudo, Á. J. A., Sado, R. Y., Borghesi, R., \& Dairik, J. K. (2010). A piscicultura e o ambiente: o uso de alimentos ambientalmente corretos em piscicultura. Revista Brasileira de Zootecnia, 39, 68-87. http://dx.doi.org/10.1590/S1516-35982010001300009.

Della Flora, M. A., Maschke, F., Ferreira, C. C., \& Pedron, F. A. (2010). Biologia e cultivo do Dourado (Salminus brasiliensis). Acta Veterinaria Brasilica, 4(1), 7-14.

Ferreira, P. M. F., Barbosa, J. M., Santos, E. L., Souza, R. N., \& Souza, S. R. (2011). Avaliação do consumo de oxigênio da tilápia do Nilo submetidas a diferentes estressores. Revista Brasileira de Engenharia de Pesca, 6(1), 56-62.

Garcia, E. E. S. (2015). Método de Índice de Qualidade (QIM) otimizado para aferição da vida útil da tilápia do Nilo (Oreochromis niloticus) (Master's dissertation). Escola Superior de Agricultura "Luiz de Queiroz", Universidade de São Paulo, Piracicaba.

Higuchi, L. H., Feiden, A., Maluf, M. L. F., Dallagnol, J. M., Zaminhan, M., \& Boscolo, W. R. (2011). Avaliação eritrocitária e bioquímica de jundiás (Rhamdia quelen) submetidos à dieta com diferentes níveis protéicos e energéticos. Ciência Animal Brasileira, 12(1), 70-75.

Huss, H. H. (1995). Quality and quality changes in fresh fish. Fisheries Technical Paper, 348(1), 195-198.

Jorgensen, J. B., \& Mustafa, T. (1980). The effect of hypoxia on carbohydrate metabolism in flounder (Platichthys flesus L.) - II. High energy phosphate compounds and the role of glycolytic and gluconeogenetic enzymes. Comparative Biochemistry and Physiology Part B: Comparative Biochemistry, 67(2), 249-256. http://dx.doi. org/10.1016/0305-0491(80)90140-6.

Jory, D. E., Alceste, C., \& Cabrera, T. R. (2000). Mercado y comercialización de tilapia em los Estados Unidos de Norte américa. Panorama Acuícola, 5(5), 50-53.

Kestin, S. C., Wotton, S. B., \& Gregory, N. G. (1991). Effect of slaughter by removal from water on visual evoked activity in the brain and reflex movement of rainbow trout (Oncorhynchus mykiss). The 
Veterinary Record, 128(19), 443-446. http://dx.doi.org/10.1136/ vr.128.19.443. PMid:1858271.

Kubitza, F. (2000). Tilápia: tecnologia e planejamento na produção comercial (1st ed.). Jundiaí: Acqua Imagem.

Lanzarin, M., Ritter, D. O., Novaes, S. F., Monteiro, M. L. G., Almeida, E. S., Fo., Mársico, E. T., Franco, R. M., Conte Jr, C. A., \& Freitas, M. Q. (2016). Quality index method (QIM) for ice stored gutted amazonian pintado (Pseudoplatistoma fasciatum $\mathrm{x}$ Leiarius marmoratus) and estimation of shelf life. LWT - Food Science and Technology, 65(1), 363-370. http://dx.doi.org/10.1016/j.lwt.2015.08.019.

Morgan, J. D., \& Iwana, G. K. (1997). Measurements of stressed states in the field. In G. K. Iwana, A. D. Pickering, J. P. Sumpter, \& C. B. Schreck (Eds.), Fish stress and heatlh in aquaculture (chap. 5, pp. 247-270). Cambridge: Cambridge University Press.

Morzel, M., Chambon, C., Lefèvre, F., Paboeuf, G., \& Laville, E. (2006). Modifications of trout (Oncorhynchus mykiss) muscle proteins by preslaughter activity. Journal of Agricultural and Food Chemistry, 54(8), 2997-3001. http://dx.doi.org/10.1021/jf0528759. PMid:16608221.

Oetterer, M., Galvão, J. A., \& Savay-da-Silva, L. K. (2014). Tilápia: controle de qualidade, beneficiamento e industrialização: tilápia minimamente processada. In J. A. Galvão, \& M. Oetterer (Eds.), Qualidade e processamento de pescado (chap. 7, pp. 183-206). São Paulo: Elsevier.

Oliveira, P. R. C., Fo., Oliveira, C. A. F., Sobral, P. J. A., Balieiro, J. C. C., Natori, M. M., \& Viegas, E. M. M. (2015). How stunning methods affect the quality of Nile tilapia meat. Journal of Food, 13(1), 56-62.

Pedrazzani, A. S., Carneiro, P. C. F., Kirschnik, P. G., \& Molento, C. F. M. (2009). Impacto negativo de secção de medula e termonarcose no bem-estar e na qualidade da carne da tilápia do Nilo. Revista Brasileira de Saúde e Produção Animal, 10(1), 188-197.

Poli, B. M., Parisi, G., Scappini, F., \& Zampacavallo, G. (2005). Fish welfare and quality as affected by pre-salughter and slaughter management. Aquaculture International, 13(1-2), 29-49. http:// dx.doi.org/10.1007/s10499-004-9035-1.

Prata, L. F. (1999). Higiene e inspeção de carnes, pescado e derivados (1st ed.). São Paulo: UNESP.
Rahmanifarah, K., Shabanpour, B., \& Sattati, A. (2011). Effects of clove oil on behavior and flesh quality of common carp (Cyprinus carpio L.) in comparison with pre-slaughter $\mathrm{CO}_{2}$ stunning, chilling and asphyxia. Turkish Journal of Fisheries and Aquatic Sciences, 11, 139-147.

Ritter, D. O., Lanzarin, M., Novaes, S. F., Monteiro, M. L. G., Almeida Filho, E. S., Mársico, E. T., Franco, R. M., Conte-Junior, C. A., \& Freitas, M. Q. (2016). Quality index method (QIM) for gutted icestored hybrid tambatinga (Colossoma macropomum x Piaractus branchypomum) and study of shelf life. LWT - Food Science and Technology, 67(1), 55-61. http://dx.doi.org/10.1016/j.lwt.2015.10.041.

Sarmiento, A. M. L. (2006). Características microbiológicas, físico-químicas e sensoriais de filés de tilápias (Oreochromis niloticus) conservados em atmosfera modificadas sob refrigeração (Master's dissertation). Universidade Federal de Viçosa, Viçosa.

Scherer, R., Augusti, P. R., Steffens, C., Bochi, V. C., Hecktheuer, L. H., Lazzari, R., \& Emanuelli, T. (2006). Effect of slaughter method on postmortem changes of grass carp (Ctenopharyngodon idella) stored in icesti. Journal of Food Science, 70(5), 348-353. http://dx.doi. org/10.1111/j.1365-2621.2005.tb09965.x.

Soares, V. F. M., Vale, S. R., Junqueira, R. G., \& Glória, M. B. A. (1998). Teores de histamina e qualidade físico-química e sensorial de file de peixe congelado. Ciência e Tecnologia de Alimentos, 18(4), 12-24. http://dx.doi.org/10.1590/S0101-20611998000400020.

Teixeira, M. S., Borges, A., Franco, R. M., Clemente, S. C. S., \& Freitas, M. Q. (2009). Método de índice de qualidade (QIM): desenvolvimento de um protocolo sensorial para corvina (Micropogonias furnieri). Revista Brasileira de Ciência Veterinária, 16(2), 83-88. http://dx.doi. org/10.4322/rbcv.2014.175.

Urbinatti, E. C., Abreu, J., Camargo, A., \& Parra, M. (2004). Loading and transport stress in juvenile matinxã (Brycon cephalus) at various densities. Aquaculture, 229(4), 389-400. http://dx.doi.org/10.1016/ S0044-8486(03)00350-8.

Vargas, C. S. (2011). Avaliação de métodos de abate sobre a qualidade da carne de matrinxã (Brycon cephalus), armazenados em gelo (Master's dissertation). Universidade de São Paulo, Pirassununga. 